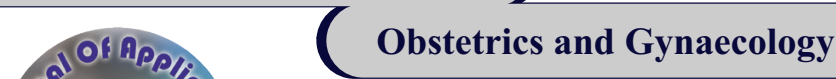 \\ ASSOCIATION OF GENITOURINARY TRACT INFECTION IN PRETERM LABOUR
}

\section{Shakti Jain*}

\section{Urvashi Barman Singh}

\section{Yashi Srivastava}

Assistant Professor, Department Of Obstetrics And Gynaecology, MLN Medical College, Prayagraj. *Corresponding Author

Associate professor, Department of obstetrics and gynaecology, MLN Medical

College, Prayagraj.

\section{Resident, Department of obstetrics and gynaecology, MLN Medical College, Prayagraj.}

Subject and methods: This was case control study conducted over one year.100 pregnant women having PTL without risk factors with intact membrane were compared with 100 pregnant women having labour at $>37$ weeks. The two groups were screened for urinary and vaginal infections. At delivery further swabs were taken from foetal surface of placenta.

Conclusion: Our study demonstrated that genitourinary tract infection is the major factor in aetiopathogenesis of preterm labour. Therefore screening for genitourinary tract infection is strongly recommended to be included in prenatal care.

KEYWORDS : Preterm labour, risk factors, genitourinary tract infection

\section{INTRODUCTION}

Preterm labour is defined as labour starting spontaneously before 37 completed weeks of gestation. Preterm birth causes most of neonatal mortality and morbidity. Any strategy which aims at reducing incidence of PTL will go a long way in decreasing perinatal and early neonatal mortality, reducing financial burden and making more bed available in NICU for managing children with other problems.

The causes of PTL in most cases have not been established but several risk factors have been identified associated with it. These factors include poor socioeconomic status, illiteracy, multiparity, maternal age $<20$ years and $>35$ years, previous PTL and genitourinary tract infections. In last 10-15 years a number of studies were conducted to search for infections as possible aetiology for preterm labour.

Romero et al (1993) ${ }^{1}$ found evidence of infection in $9.2 \%$ of 120 women with PTL with intact membranes. Zahra et al $(2014)^{2}$ have been studied maternal concentration of CRP value diagnosing subclinical infections in women with PTL. In order to evaluate the role of genitourinary infections in the aetiology of PTL, we carried out a study of women admitted with preterm labour in department of obstetrics and gynaecology, SRN hospital, Prayagraj.

\section{MATERIALS AND METHODS}

This case control study was performed in pregnant women who were in labour and admitted in department of obstetrics and gynaecology, SRN hospital, Prayagraj. The women were enrolled from April 2018 to March 2019. The study group (PTL group) consisted of 100 women admitted for PTL ( $<37$ gestational weeks) with intact membrane. The control group (Term labour group) consisted of 100 women admitted for term labour ( $>37$ gestational weeks) without any complications of pregnancy. The gestational age was based on last menstrual period combined with ultrasonographic data.

\section{Exclusion Criteria}

Women with any of the following factors were excluded from the study group. Gestational age less than 20 weeks, any congenital foetal anomaly, placenta previa, abruptio placentae, polyhydramnios, intrauterine death, medical complications, $\mathrm{Rh}$ isoimmunization, abdominal trauma, suspected or proven rupture of membranes.

\section{Data collection and sampling}

A detailed history was taken with special reference to age, parity, education, occupation, addiction to smoking and alcohol intake and socioeconomic status. A detailed obstetric history with reference to parity, preterm pain, number of preterm delivery, number of abortions and multiple pregnancy was taken. Menstrual history regarding first day of last of menstrual period, expected date of delivery and previous menstrual cycle was taken. Clinical examination and routine investigations were done.

Urine sample of each woman was collected for routine and bacteriological examination. The counts were calculated as colony forming units $\mathrm{CFU} / \mathrm{ml}$. Growth of 1 or 2 isolates of possible pathogens at a concentration of $>10^{5} \mathrm{CFU} / \mathrm{ml}$ was considered and these isolates were identified.

A sterile speculum was used to take cervical and high vaginal swabs and put into media for transport to pathological unit.

At delivery, further swabs were taken from foetal surface of placenta put into media and sent to pathological unit.

\section{Observations}

The age of women in our study lie between 20 to 40 years and most of the patients were primigravida of low socioeconomic status.

Table-1 shows that the maximum number of women presented between 28-32 weeks of gestation.

\begin{tabular}{|l|l|c|c|}
\hline S No. & Gestational age (weeks) & No. of women & Percentage $\%$ \\
\hline 1. & $<28$ weeks & 16 & 16 \\
\hline 2. & $28-32$ weeks & 60 & 60 \\
\hline 3. & $33-36$ weeks & 24 & 24 \\
\hline Total & & 100 & 100 \\
\hline
\end{tabular}

Table- 2 shows the incidence of bacteriuria in study and control group $(>105 \mathrm{CFU} / \mathrm{ml})$

\begin{tabular}{|l|l|l|l|l|}
\hline \multirow{2}{*}{ Type of bacteria } & \multicolumn{3}{|l|}{ Study group $(\mathrm{n}=100)$} & \multicolumn{2}{l|}{ Control group $(\mathrm{n}=100)$} \\
\cline { 2 - 5 } & No. & $\%$ & No. & $\%$ \\
\hline E.coli & 25 & 25 & 8 & 8 \\
\hline Klebseilla & 6 & 6 & 2 & 2 \\
\hline Strept. faecalis & 5 & 5 & 3 & 3 \\
\hline B.proteus & 3 & 3 & 1 & 1 \\
\hline Strept. viridans & 5 & 5 & 3 & 3 \\
\hline Total & 44 & 44 & 17 & 17 \\
\hline
\end{tabular}

Table-3 shows the incidence of positive bacterial culture of high vaginal and cervical swabs in study and control groups.

\begin{tabular}{|c|c|c|c|c|}
\hline \multirow[t]{2}{*}{ Type of bacteria } & \multicolumn{2}{|c|}{\begin{tabular}{|l|} 
Study \\
group $(\mathrm{n}=100)$
\end{tabular}} & \multicolumn{2}{|c|}{$\begin{array}{l}\text { Control } \\
\text { group }(n=100)\end{array}$} \\
\hline & No. & $\%$ & No. & $\%$ \\
\hline Strept. viridans & 7 & 7 & 1 & 1 \\
\hline Strept. faecalis & 7 & 7 & 1 & 1 \\
\hline Anaerobic streptococci & 6 & 6 & - & - \\
\hline
\end{tabular}


Volume-10 | Issue-1 | January - 2020 | PRINT ISSN No. 2249 - 555X | DOI : 10.36106/ijar

\begin{tabular}{|l|l|l|l|l|}
\hline \hline E.coli & 7 & 7 & 1 & 1 \\
\hline Klebsiella & 5 & 5 & - & - \\
\hline Bacteroids & 4 & 4 & - & - \\
\hline Trichomonas vaginalis & 20 & 20 & 1 & 1 \\
\hline Candida albicans & 16 & 16 & 10 & 10 \\
\hline Mycoplasma hominis & 7 & 7 & - & - \\
\hline Ureaplasma ureolyticum & 8 & 8 & 1 & 1 \\
\hline Total & 87 & 87 & 14 & 14 \\
\hline
\end{tabular}
influence of bacterial vaginosis on gestational week of the completion of delivery and biochemical markers of inflammation in the serum Vojnosanit Pregl, 71 (2014), pp.931935

Table-4 shows distribution of cases according to histopathological examination.

\begin{tabular}{|l|l|l|l|l|}
\hline \multirow{2}{*}{ Group } & \multicolumn{2}{|l|}{$\begin{array}{l}\text { Study } \\
\text { group }(\mathrm{n}=100)\end{array}$} & \multicolumn{2}{|l|}{$\begin{array}{l}\text { Control } \\
\text { group }(\mathrm{n}=100)\end{array}$} \\
\cline { 2 - 5 } & No. & $\%$ & No. & $\%$ \\
\hline $\begin{array}{l}\text { Aggregation of neutrophils } \\
\text { under chorionic plate }\end{array}$ & 10 & 10 & 2 & 2 \\
\hline $\begin{array}{l}\text { Neutrophil permeation of } \\
\text { chorionic plate }\end{array}$ & 6 & 6 & - & - \\
\hline $\begin{array}{l}\text { Inflammation of umblical } \\
\text { cord and membranes }\end{array}$ & 3 & 3 & 1 & 1 \\
\hline Total & 19 & 19 & 3 & 3 \\
\hline
\end{tabular}

Incidence of significant bactereuria was $44 \%$ in study group as compared to $17 \%$ in control group (table1). Incidence of positive bacterial culture of high vaginal and cervical swabs was quite high i.e. $87 \%$ compared to control group (14\%) (table 2 ). Table 4 shows that chorioamnionitis was present in $19 \%$ of study group compared to $3 \%$ in control group.

\section{DISCUSSION}

In our study incidence of urinary tract infections was twice more common in women who delivered before 37 gestational weeks compared to antenatal term control (table 2). S.R. Dimetry et al (2007) ${ }^{3}$ also explained role of urinary tract infections in the aetiopathogenesis of PTL. In our study incidence of positive bacterial culture of high vaginal swabs and cervical swabs was quite high i.e. $87 \%$ in women with PTL compared to control group 14\% (table 3). This view was supported by Holst et al $(1994)^{4}$, J.C. Carey et al $(2005)^{5}$ and A. Jakovljevic et al (2014) 9

Our study showed that the incidence of chorioamnionitis was significantly higher in women with spontaneous PTL compared to control (table 4). Zahra et al (2014) ${ }^{2}$ also described in their study that abnormal colonisation of genital tract leads to preterm delivery. It is suggested that the infection of the foetal membrane occurs as an ascending infections from maternal cervical and vaginal flora. Hence maternal genital infections have an important role in etiopathogenesis of preterm labour. This view was supported by Romero et al (1993)', Kuboto (1998) and Gractacos et al $(1998)^{8}$

\section{CONCLUSION}

In our study we concluded that genitourinary tract infection is a major cause of spontaneous preterm labour. The current evidence suggests that for women in preterm labour antibiotics may be of help particularly if used in conjunction with tocolytics. More extensive studies are required to support our findings.

\section{Compliance with ethical standards \\ Conflict of interest: None.}

Disclaimer: nil

Informed consent: informed written consent was received from all the participants.

\section{REFERENCES:}

1. Romero, R., Sibai, B. \& S. Caritis (1993): Am. J. Obstet. Gynae., 169:764-774.

2. Zahra shahshahan and Ousha Rasouli Theuse of maternal C-reactive protein in the prediction of preterm labour 2014 Jul 31

3. S.R. Dimetry, H.M. EL-Tokhy, N.M. Abdo, M.A. Ebrahim, M. Eissa Urinary tract infection and adverse outcome of pregnancy j Egypt Public Health Assoc, 82 (2007), pp. 203-218

4. E. Holst, A.R. Goffeng, B. Andersch bacterial vaginosis and vaginal microorganism in idiopathic premature labour and association with pregnancy outcome Clin Microbiol, 32 (1994), pp.176-186.

5. J.C. Carey, M.A. Klebanoff is a change in the vaginal flora associated with an increased risk of preterm birth? Am J Obstet Gynaecol, 192 (2005), pp. 1341-1346.

6. L.F. Cram, M.I. Zapata, E.C. Toy, B. Baker 3rd genitourinary tract infections and their association with preterm labour Am Fam Physician, 65 (2002), pp. 241-248

7. Kubota, T. (1998): Br. J. Obstet Gynaecol., 92:926-930.

8. Gractacos, E. \& F. Figueras (1998): Acta Obst. Gynae. Scand., 77:37-40 